\title{
IMPACT OF KHAT (CATHA EDULIS) CHEWING/USE ON HEART RATE AND BLOOD PRESSURE: A CRITICAL REVIEW
}

\author{
Zhi Xiong Chong ${ }^{1}$, Mustafa Alshagga ${ }^{1 *}$, Khaled Ahmed Saed ${ }^{2}$ and Saba Kassim ${ }^{3}$ \\ ${ }^{1}$ Department of Biomedical Science, Faculty of Science, University of Nottingham Malaysia Campus, Semenyih, Malaysia \\ ${ }^{2}$ Department of Surgery, Faculty of Medicine, Aden University, Yemen \\ ${ }^{3}$ Taibah University Dental College and Hospital (TUDCH), Al-Madinah Al-Munawwarah, Saudi Arabia
}

\author{
Corresponding author: \\ *Mustafa Alshagga \\ Mustafa.al-shagga@nottingham.edu.my, Yamosta@gmail.com
}

\begin{abstract}
Khat leaves chewing/use, which imparts amphetamine like effects on the user, is widely practiced in parts of Africa, the Arabian Peninsula, and among the diaspora communities from these regions. Basic clinical and epidemiological studies from different settings have reported associations of acute coronary syndrome, heart failure, and cardiomyopathy, with khat chewing / use. This review aims to analyse the current evidence of the impact that khat, or its active constituent, cathinone, has on the cardiovascular system (CVS), particularly in two parameters, heart rate (HR) and blood pressure (BP). Subsequently, the possible mechanism of actions of how khat impacts these cardiovascular parameters is discussed, and different studies' findings are summarised appropriately. The analysis of literature suggests that khat could influence HR and BP by most likely causing tachycardia and hypertension and the impacts might be dose-dependent and time-dependent. However, most of the studies involved different species and study designs, and had different limitations. Additionally, the underlying mechanisms of khat effects on these CVS parameters remain unclear. Therefore, more studies are needed to further support the current evidence of the impacts that khat has on the CVS parameters of HR and BP.

Keywords: Khat, cardiovascular system (CVS), heart rate, blood pressure, cathinone, Review
\end{abstract}

\section{INTRODUCTION}

Khat or Catha edulis is a common recreational drug used/chewed in Africa and Arabic regions especially in Yemen, Ethiopia and Somalia. It has a slightly sweet taste and an aromatic smell that attracts people to chew it for recreational purpose $^{1}$. The main khat components include cathinone, cathine, norephedrine, and pseudoephedrine. Cathinone and cathine are the most active bio-compounds of khat ${ }^{2}$. Cathinone has structural and functional similarities to indirectly-acting sympathomimetic agents like amphetamine. Excessive khat consumption is related to mood disorders, metabolic disorders, and cardiovascular diseases ${ }^{2-4}$. Frequent khat use is also suggested to have negative impacts on the socio-economic function of an individual, as well as on the country at large 1 .

For the past 25 years, numerous studies have shown that excessive khat use could lead to acute coronary syndrome, cardiomyopathy, and heart failure ${ }^{4}$. Structural mimicry between khat constituents and indirectly-acting sympathomimetic agents allows it to activate the sympathetic nervous system, thereby elevating the blood pressure and the heart rate ${ }^{3}$. Specifically, the impact of khat and ethanolic extracts of its active constituent, cathinone, on the cardiovascular system (CVS) parameters of heart rate (HR) and blood pressure (BP) have been reported from different settings s $^{1,3-5}$. However, there is a gap in knowledge to substantiate the aforementioned findings. Therefore, this review aimed to assess and summarise the impacts of khat on HR and BP.

\section{METHODS}

A systematic database search was performed in March 2017 to look for relevant articles on the impact of khat on the cardiovascular system (CVS), and the study method (Figure 1) was adopted from previous systematic review studies $2,6,7$. Four electronic databases, namely PubMed, NUsearchUK, Web of Science and Science Direct, were employed for the literature search. Khat-related keywords like Catha edulis, khat, qat, mirra and murungu, and Khat bio-substance-related terms like cathinone, norephedrine, pseudoephedrine and cathine were used during the search. CVS parameters which were used in the search included heart rate, tachycardia, blood pressure, hypertension, and myocardial infarction. All relevant quantitative studies, either crosssectional or experimental studies, and any clinical trials that involved animals or humans were included. The excluded studies were systematic reviews, case reports, letters to the editor, articles written in languages other than English, duplicated articles, khat studies on non-CVS parameters, and any other articles which were unrelated to both khat and CVS. 


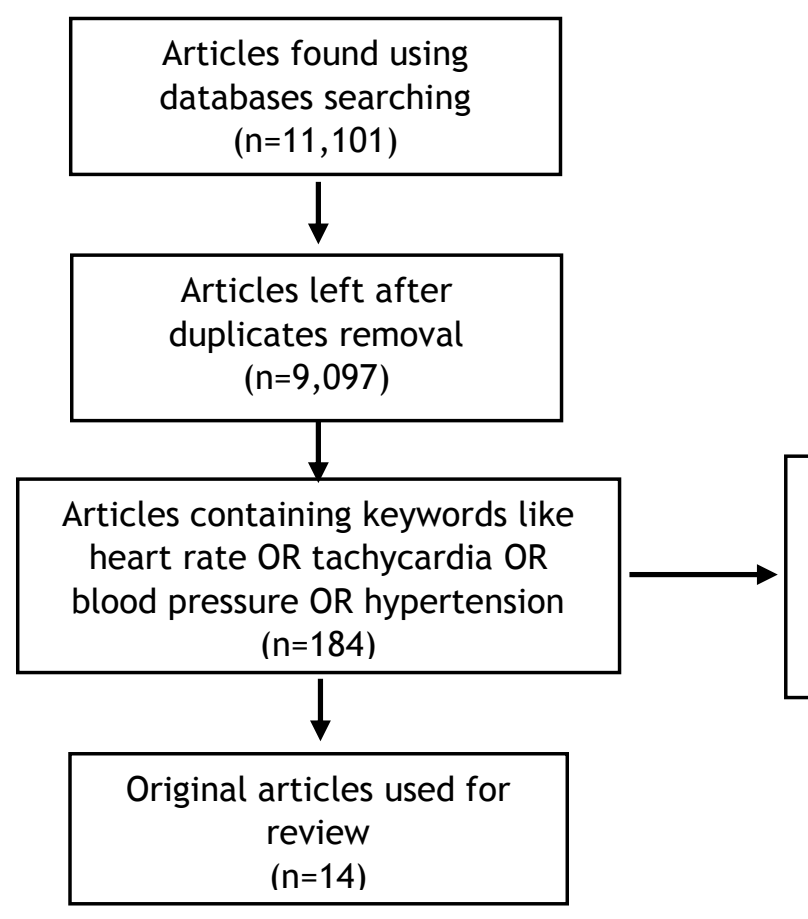

Excluded articles: Literature reviews, commentary, case reports, articles about khat effects in pregnancy, paediatric studies etc. $(n=170)$

Figure 1: Study flowchart which was modified from a previous study on approach to report systemic reviews ${ }^{46}$.

\section{RESULTS}

\section{The effects of Khat on Heart Rate}

Kha thas been shown to increase the heart rate (Appendix table 1)in some animal and human studies $^{8-11}$. In one animal study ${ }^{11}$, male Wistar rats $(n=10)$ were supplied with $3 \mathrm{~g} / \mathrm{kg}$ of the rat's weight (equivalent to $0.5 \mathrm{~g} / \mathrm{kg}$ consumption among khat chewers) of oral khat leave extract. Maximal heart rate was recorded at 40 minutes post-khat administration (study duration: 1 hour),accompanied by decreased atrial depolarisation (PR waves) and prolonged ventricular repolarisation (QT waves) intervals ${ }^{11}$. The increase in the heart rate was significant $(p<0.05)$ when comparing control and khattreated rats and the heart rate differed by 5 to $12.8 \%$ between both groups at different intervals. Khat-induced tachycardia were also reported in human studies using the active compound of khat (cathinone). In a human placebo-controlled study ( $n=6$, male)subjects were administered cathinone at a concentration of $0.5 \mathrm{mg} / \mathrm{kg}$, and the subjects' heart rates were observed for 8 hours after administration ${ }^{8}$.Compared to the control, heart rate among cathinone-treated group was very significantly elevated $(p<0.001)$.

Another human study used cathinone concentrations of $0.8 \mathrm{mg} / \mathrm{kg}$, and the study duration was 9 hours but the increase in the heart rate among cathinone-treated group was insignificant $(p>0.05)^{9}$. Both the animal and human studies have been recorded the heart rate at regular intervals after drug administration. Regardless of the variation in dosage, khat leave extracts and cathinone have been shown to increase heart rates in both animal and human. This possibly suggests that cathinone is one of the primary bioactive compounds of khat that causes an acceleration of heart rate. The main difference between the animal and human studies was found in the timing of the onset of the increasing heart rate. The maximal heart rate was noted at 2 hours post-khat administration in the human study 9 compared to the 40 minutes in the rat study ${ }^{11}$. Literature has suggested that plasma cathinone level usually peaks at 2 to 3 hours after oral administration in human, and so it is expected that the maximal heart rate was observed at 2 hours post-cathinone administration 9,12. One possible reason to explain the faster onset of maximal heart rate in rats is the higher dose of the extract which may have caused a speedier drug absorption and distribution rate in rats than in human. There are probably additional components of khat extract that could affect heart rate, or it may also be possible that some other unclear drug-body interaction exists that could have led to a quicker drug absorption and action, which might be interesting to study further ${ }^{13-15}$.

An experimental crossover human study has been carried out in Saudi Arabia ( $\mathrm{n}=21$; unspecified gender) showed that chewing $45 \mathrm{~g}$ of khat leaves significantly induced tachycardia $(p<0.05)$ among the participants during and after exercise compared to placebo ingestion ${ }^{16}$. The mean heart rate \pm standard deviation (SD) of the khat-treated group was $15.8+11.5$ beats per minute (bpm) higher than the control group. This finding indicates an additional impact of khat on heart rate, over the accelerated heart rate induced by 
exercise. A crucial limitation of the study was the inability to differentiate the baseline heart rate of the participants, and an absence of information on any history of life-related stressors and exercise tolerance before khat administration ${ }^{17}$. Regular exercise is well-known to accelerate the heart rate via sympathetic nervous system activation, compared to placebo in many studies $^{18,19}$, but in the long-term, exercise actually lowers both stress and heart rate.

Another cross-sectional human study ( $\mathrm{n}=664$; mixed gender) in Ethiopia has shown that the mean heart rate among khat chewers (76.3 \pm $11.5 \mathrm{bpm})$ was significantly higher $(p<0.05)$ than non-chewers $(73.9 \pm 12.6 \mathrm{bpm})^{20}$. Even though this study has used a validated questionnaire and a consistent data collection method, it could still be biased based on the self-reporting of results. Additionally, the number of participants who have habits of smoking and drinking coffee were significantly higher among the chewers than the non-chewers. Since the half-life of caffeine ranges from 2 to 12 hours ${ }^{21,22}$, and cathinone and cathine half-lives are $1.5 \pm 0.8$ hours and $5.2 \pm 3.4$ hours, respectively ${ }^{12}$, it is unclear whether it was caffeine or khat that induced the tachycardia. Also, it is unclear whether the chewers consumed similar khat doses every day, and the heart rate measurements were taken between 8.30am and $6.30 \mathrm{pm}$, independent of the timing of khat ingestion ${ }^{20}$. It is unclear if the difference in heart rate between khat chewers $(76.3 \pm 11.5 \mathrm{bpm})$ and non-chewers $(73.9+12.6 \mathrm{bpm})$ would have a tangible clinical significance rather than just statistical significance.

Studies that attempted to explore the mechanism of action of khat effect on heart rate are scant. A human, double-blinded, 3 arm cross-over, placebo-controlled study ( $n=63$; all male) involving khat, indoramin (selective a1-blocker) and atenolol (selective B1-blocker), showed that atenolol could potentially reduce $(p<0.05)$ the significantly elevated heart rate induced by khat, but could not do so for elevated heart rates as a result of indoraminadministration ${ }^{10}$. This suggests that heart rate acceleration among khat chewers is mediated by $\mathrm{B1}$-adrenoceptors rather than a1adrenoceptors. Once activated, a G-protein coupled receptor (Gs-coupled $ß 1$-adrenoceptor) dissociates, activates adenylyl cyclase (AC), and increases cytosolic cyclic adenosine monophosphate (cAMP)which activates $\mathrm{Ca}^{2+}$ channels ${ }^{19}$. This $\mathrm{Ca}^{2+}$ influx promotes actinmyosin interactions, increases heart contraction forces, and causes tachycardia ${ }^{19}$. Definitive knowledge of a direct effect of khat or cathinone at the receptor level is lacking. Nevertheless, the structural similarity between cathinone and amphetamine allows for cathinone to function as an indirectly-acting sympathomimetic agent. Amphetamine could promote the release of monoamines and reduces their reuptake, thus, increasing dopamine, noradrenaline and serotonin levels in the synaptic cleft ${ }^{4}$. This causes sympathetic over-activity and tachycardia. So, if cathinone could act like amphetamine in causing sympathetic over-activity, this would highlight a central, rather than peripheral effect of khat or cathinone on heart rate ${ }^{4}$. Moreover, the standard dose of khat used in the 3 arms probably neglected the differential affinity of adrenergic receptors for sympathomimetics ${ }^{10}$.

On the contrary, an organ bath study (90 seconds) using male albino rabbits heart tissue $(n=6)$ showed that khat extract significantly $(p<0.05)$ decreased heart rate in a concentration- and time-dependent manner by exerting negative inotropic and chronotropic effects ${ }^{1}$. Compared to the rat and human in vivo studies that showed khat-induced tachycardia ${ }^{8,9,11}$, this ex vivo study 1 used 50,100 and $250 \mathrm{mg} / \mathrm{mL}$ of khat extracts (extracted using 70/30\% water: ethanol). It could be the difference in the study design and the variation in the khat concentration used that would explain why bradycardia was observed 23,24 . The exact mechanism that caused this phenomenon is unclear, but Al-Hashem et al. suggested that khat might alter membrane ion movements $\left(\mathrm{Ca}^{2+}, \mathrm{Na}^{+}\right)$that can delay depolarisation, thus causing bradycardia, which reduces coronary perfusion and induces myonecrosis ${ }^{1}$. Khat-induced noradrenaline release could indirectly trigger a1-adrenoceptordependent coronary vasoconstriction by promoting $\mathrm{Ca}^{2+}$ ion entry into vascular smooth muscle, thus worsening myocardial perfusion and further depressing cardiac contractility ${ }^{1}$. Several case reports also have suggested a possible association between khat consumption and coronary vasoconstriction ${ }^{25,26}$. Major drawbacks of the ex vivo study include the use of the whole khat extract without simultaneous comparison to the khat active compound (cathinone), in addition to the presence of tannins and flavonoids in khat extract which probably have inhibitory cardiac effects by anti-cholinergic or anti-histaminic mechanisms ${ }^{27,28}$.

Generally, based on the different reports in the literature in which the relationships between khat, or cathinone, consumption and heart rate have been studied, it is shown that khat, or cathinone, plays some kinds of role in accelerating the heart rate. However, all these studies did not explain in detail the impact of khat on stroke volume, myocardial contractility and cardiac output, or identify secondary neuro-hormonal mechanisms that could elicit changes in heart rate. In addition, most reported studies ${ }^{1,8-11,16}$ have limitations such as the use of different samples like khat leaves extracts vs cathinone active compounds, different compounds concentration, short study duration (generally ranging from several hours to several months), small sample size (generally $n<100$ ), lack of repeated study results, and recruitment of only males in both rat and human studies, which raises gender bias concerns. Any or all of these 
limitations would probably affect the various study findings ${ }^{29-31}$

\section{The effects of Khat on Blood Pressure}

As noted in the aforementioned studies, khat, or its active alkaloid cathinone, influences both heart rate and contractility, and therefore, increases in cardiac output, which is a major determinant of mean systolic blood pressure. All pooled studies in this review are summarised (Appendix table 2). In Ethiopia, four crosssectional studies were reported, including a very large-scale study ( $\mathrm{n}=4001$; mixed gender) ${ }^{32}$ and another two smaller studies ( $\mathrm{n}=667$; mixed gender) 20 and $\left(\mathrm{n}=422\right.$; all male) ${ }^{33}$. An additional study $(n=330$; mixed gender) has focused on the population in Eastern Ethiopia ${ }^{34}$. Most studies showed that khat could significantly $(p<0.05)$ elevate diastolic blood pressure $20,32,33$. Khat chewing was shown to increase mean diastolic blood pressure with beta coefficient (B) of 1.9 compared to non-chewers ${ }^{32}$ and generally khat chewers have higher mean diastolic blood pressure $75.0 \pm 11.6$ than non-chewers $72.9 \pm 11.7$ $\mathrm{mmHg}{ }^{20}$. Besides, khat chewing was also shown to increase adjusted odd ratio (AOR) \pm confidence interval $(\mathrm{Cl})$ of diastolic blood pressure (AOR:5.43; $\mathrm{Cl}$ : 2.05-14.38) ${ }^{33}$. Systolic blood pressure was found to be elevated significantly $(p<0.05)$ only in one study (AOR:14.95; Cl:5.49-40.66) ${ }^{33}$, while insignificant systolic blood $(p>0.05)$ pressure elevations were observed in the earlier study (beta coefficient (B) of 1.6) 32 and another mentioned study also showed insignificant increase in the systolic blood pressure among khat chewers $(116.9 \pm 17.8 \mathrm{mmHg})$ compared to nonchewers $(116.1 \pm 16.8 \mathrm{mmHg})^{20}$. The insignificant systolic blood pressure elevations were not explored further. However, diastolic blood pressure has shown in most studies to be elevated by khat, which is more useful in the assessment of peripheral blood resistance ${ }^{35}$, thereby causing high blood pressure ${ }^{36,37}$. Khat chewing is also associated with an increased risk of hypertension (AOR: 1.98; $\mathrm{Cl}: 2.99-5.46){ }^{34}$. In a study conducted in Yemen, involving undergraduate medical students $(n=100 \text {; mixed gender })^{38}$, blood pressure was shown to fluctuate among the khat chewers.

On the other hand, an animal study involving male Wistar rats $(n=10)$ that were administered $3 \mathrm{~g} / \mathrm{kg}$ rat's weight of khat leave extract, and two placebo-controlled human studies $(n=6$; all male) which used $0.5 \mathrm{mg} / \mathrm{kg}$ and $0.8 \mathrm{mg} / \mathrm{kg}$ cathinone concentration, have all shown that khat, or cathinone, could possibly significantly increase $(p<0.05)$ blood pressure in vivo, in both time- and dose-dependent manners ${ }^{8,9,11}$. For the rat study ${ }^{11}$, the SBP among khat-treated rats was 8.1 to $26.3 \%$ higher than the SBP of the control while the DBP was 22 to $53.5 \%$ higher in the khat-treated group. The mean SBP and DBP differences in the two human trials were not explained further ${ }^{8,9}$. The possible mechanism of how khat induces hypertension was suggested by a human study
( $\mathrm{n}=63$; all male) in $2005{ }^{10}$. In that study, it was shown that khat-induced hypertension could be antagonized significantly $(\mathrm{p}<0.05)$ by atenolol (selective B1-blocker) but not indoramin (selective a1-blocker) ${ }^{10}$. This suggests that khatinduced hypertension is associated with B1adrenoceptor-mediated tachycardia. Increases in sympathetic activity after khat, or cathinone, administration probably could be elucidated by an increase in renin secretion from the kidney, and an increase in the activity of the renin-angiotensin aldosterone system (RAAS). The RAAS activation might cause increase in blood volume and this might increase the peripheral vascular resistance reflected in elevated diastolic blood pressure $^{36,37,39}$.

Another two organ bath experiments ( $n=$ unspecified, both used guinea pig tissue) showed that cathinone could significantly increase $(p<0.05)$ coronary vasoconstriction in a dose-dependent manner 36,37. Cathinone was shown to cause peak coronary vasoconstrictions of the guinea pig by $56.5 \pm 13.8 \%$ and $56.5 \pm 4.2 \%$ when $1 \mathrm{mM} 36$ and $300 \mu \bar{M}$ of cathinone ${ }^{37}$ were administered respectively. It was unclear why almost similar peak vasoconstriction was produced when two different cathinone concentrations were given, but it could imply that $300 \mu \mathrm{M}$ is the maximal cathinone concentration that could cause peak vasoconstriction and further increasing the cathinone concentration would not produce more vasoconstriction. On the other hand, it was postulated that khat-induced vasoconstriction is not mediated via a1adrenoceptors or indirect-acting sympathomimetic action, but could be related to the release of endogenous vasoconstrictors like endothelin and angiotensin, although the mechanism was unclear ${ }^{36,37}$. This suggests the possibility that the khat-induced vasopressor effect could be mediated by an endothelininduced release of prostaglandin and thromboxane A2 (vasoconstriction effects) ${ }^{37,39}$. Further pharmacologic and in vivo studies will be needed to verify this hypothesis ${ }^{30}$.

Interestingly, a study conducted in Yemen ( $\mathrm{n}=74$; mixed gender) suggested that khat would reduce blood pressure significantly $(p<0.05)$ in which the baseline SBP among chewers was $105.2 \pm 1.9$ $\mathrm{mmHg}$ compared to non-chewers $105.8 \pm 1.8$ whereas the baseline DBP was $68.2 \pm 1.6$ among chewers compared to $71.6 \pm 1.6$ among nonchewers. To the best of our knowledge, this is the only report that suggests such a possibility ${ }^{40}$. This study did not explain the underlying mechanism, but instead, correlated reduced cognitive function and blood pressure to khat usage ${ }^{40}$. In this study, the khat consumption habits of the participants were standardized (chewed 5 hours/day, 5 times/week for almost 6 years), but the consumption dosage was unclear. Therefore, it could be the consumption dosage that explained why khat led to lowered blood pressures. 
Different khat, or cathinone, concentrations might be associated with different selectivity towards the adrenergic receptor. In this study, it could be the activation of the a2-adrenergic receptors that led to sympathetic outflow inhibition and hypotension ${ }^{19}$. Since the reported usual cathinone concentration that is associated with hypertension is $0.5-0.8 \mathrm{mg} / \mathrm{kg}{ }^{8,9}$, it might be that a lower or higher cathinone concentration consumption favours a2-adrenergic receptor occupancy, but more studies will be needed to validate this hypothesis.

Many of the reported studies suggested possible associations between khat consumption and hypertension. However, most of these studies only focused on the Yemeni and Ethiopian populations ${ }^{20,32-34,38}$ which did not take into consideration potential inter-population variations ${ }^{41}$. Most cross-sectional studies ${ }^{20,32-}$ ${ }^{34,38}$ did not really standardize or mention the khat consumption habits or usages among the participants, which is significant because different dosages consumed might affect blood pressure differently ${ }^{42}$.

There were some studies ${ }^{34}$ in which the investigators ensured that the participants did not smoke or drink caffeine before their blood pressure measurements, since these substances could have potentially affected the results ${ }^{43}$, but other studies ${ }^{20,32,33,38}$ did not document that these factors had been taken into consideration. The timing of the blood pressure measurements could have also affected the validity of the results ${ }^{44}$. One study measured the blood pressure independent of the timing of khat consumption ${ }^{20}$, while another study measured the blood pressure at least 14 hours-post khat administration ${ }^{38}$ which is problematic because the khat plasma concentration would likely have dropped drastically so long after administration due to drug metabolism ${ }^{45}$. In another two studies ${ }^{32,33}$, it is unclear when the blood pressure was taken. As for the study duration and sample size (n), crosssectional studies generally employed a large sample size (n)and a long study duration, with the exception of the reported animal and human experimental studies ${ }^{1,8-11,40}$, which used relatively small $\mathrm{n}$ and short study durations. Most of the cross-sectional studies also had participants of both genders in their studies, with the exception of one cross-sectional study ${ }^{33}$. The reported animal and human non-cross-sectional studies ${ }^{8-11}$, only males were employed and this likely caused gender bias ${ }^{29}$.

\section{CONCLUSION AND FUTURE DIRECTIONS}

This review comprehensively summarises and assesses the findings from different studies where khat had been suggested to influence the heart rate and blood pressure, but the evidences were inconclusive due to the different studies' limitations. Future cross-sectional studies should focus on multiple ethnicities, as current studies mainly focus on African and Arabic populations. Other parameters like khat chewing / use history, blood pressure measurement techniques, and timing of blood pressure measurement should be standardized to ensure reliability of the results.

Animal and human experimental studies should focus on obtaining participant subjects of both genders, in order to avoid the inability to standardize or generalize results due to gender biases. It is also advisable to use larger sample sizes and longer study durations to test the impact of khat in vivo. There are still some gaps to be filled in the literature, with regard to the exact mechanism of how khat affects different CVS parameters. Therefore, more studies should be done in the future to further establish the relationship between khat and adverse cardiovascular outcomes, as well as to identify the exact underlying molecular mechanisms.

Declaration of interest: The authors report no conflicts of interest. The authors alone are responsible for the content and writing of the paper.

\section{REFERENCES}

1. Al-Hashem FH, Dallak MA, Nwoye LO, et al. Acute exposure to Catha edulis depresses contractility and induces myocardial infarction in spontaneously contracting, isolated rabbit's heart. Saudi J Biol Sci. 2012;19(1):93-101.

doi:10.1016/j.sjbs.2011.01.002.

2. Alshagga MA, Alshawsh MA, Seyedan A, et al. Khat (Catha edulis) and obesity: A scoping review of animal and human studies. Ann Nutr Metab. 2016;69(34):200-211. doi:10.1159/000452895.

3. Ali WM, Al Habib KF, Al-Motarreb A, et al. Acute coronary syndrome and khat herbal amphetamine use: An observational report. Circulation. 2011;124(24):2681-2689. doi:10.1161/CIRCULATIONAHA.111.039768.

4. El-Menyar A, Mekkodathil A, Al-Thani H, AlMotarreb A. Khat use: History and heart failure. Oman Med J. 2015;30(2):77-82. doi:10.5001/omj.2015.18.

5. Al-Motarreb A, Al-Kebsi M, Al-Adhi B, Broadley KJ. Khat chewing and acute myocardial infarction. Heart. 2002;87(3):279-280.

doi:10.1136/heart.87.3.279.

6. Noor AA, Aljunid SM. Systematic review of factors associated with willingness to pay for health financing scheme. Malaysian $\mathrm{J}$ Public Heal Med. 2017;17(2):103-112. 
7. Khongboon P, Pongpanich S, Tangcharoensatien $V$. Well-being of the elderly in Thailand: A scoping systematic review. Malaysian J Public Heal Med. 2017;17(1):94-110.

8. Brenneisen $\mathrm{R}$, Fisch $\mathrm{H}$, Koelbing $\mathrm{U}$, Geisshusler S, Kalix P. Amphetamine-like effects in humans of the khat alkaloid cathinone. $\mathrm{Br} J$ Clin Pharmacol. 1990;30(6):825-828. doi:10.1111/j.13652125.1990.tb05447.x.

9. Widler P, Mathys K, Brenneisen R, Kalix P, Fisch $H$. Pharmacodynamics and pharmacokinetics of khat: A controlled study. Clin Pharmacol Ther. 1994;55(5):556-562.

10. Hassan NA, Gunaid AA, El-Khally FM, AlNoami MY, Murray-Lyon IM. Khat chewing and arterial blood pressure. A randomiszed controlled clinical trial of alpha-1 and selective beta-1 adrenoceptor blockage. Saudi Med J. 2005;26(4):537-541.

11. Al-Hashem FH, Shatoor AS. Acute oral administration of Khat (Catha edulis) aqueous extract elevates blood pressure and prolongs QT and QTC intervals in Wistar albino rats. Saudi Med J. 2012;33(10):1065-1072.

12. Toennes SW, Harder S, Schramm M, Niess C, Kauert GF. Pharmacokinetics of cathinone, cathine and norephedrine after the chewing of khat leaves. $\mathrm{Br} J$ Clin Pharmacol. 2003;56(1):125-130.

13. Caldwell J, Gardner I, Swales N. An introduction to drug disposition: The basic principles of absorption, distribution, metabolism, and excretion. Toxicol Pathol. 1995;23(2):102-114.

14. Shin J, Seol I, Son C. Interpretation of animal dose and human equivalent dose for drug development. J Korean Orient Med. 2010;31(3):1-7.

15. Turner $\mathrm{P} \vee \mathrm{V}$, Brabb T, Pekow C, Vasbinder MA. Administration of substances to laboratory animals: Routes of administration and factors to consider. J Am Assoc Lab Anim Sci. 2011;50(5):600613.

16. Sallam MA, Sheikh KA, Baxendale R, Azam $M N$, El-Setouhy M. The physiological and perceptual effects of plant extracts (Catha Edulis Forsk) during sustained exercise. Subst Abuse Treat Prev Policy. 2016;11(18):1-9. doi:10.1186/s13011-0160063-4.
17. Martinelli FS, Chacon-Mikahil MPT, Martins LEB, et al. Heart rate variability in athletes and nonathletes at rest and during head-up tilt. Brazilian J Med Biol Res. 2005;38(4):639-647. $879 \times 2005000400019$.

18. Mcclaran SR, Wetter TJ. Low doses of caffeine reduce heart rate during submaximal cycle ergometry. J Int Soc Sports Nutr. 2007;9:1-9. doi:10.1186/1550-2783-4-Received.

19. Becker DE. Basic and clinical pharmacology of autonomic drugs. Anesth Prog. 2012;59(4):159-168. doi:10.2344/00033006-59.4.159.

20. Getahun W, Gedif T, Tesfaye F. Regular Khat (Catha edulis) chewing is associated with elevated diastolic blood pressure among adults in Butajira, Ethiopia: a comparative study. BMC Public Health. 2010;10(390):1-8. doi:10.1186/1471-245810-390.

21. Giacomin E, Palmerini E, Ballo P, Zacà V, Bova G, Mondillo S. Acute effects of caffeine and cigarette smoking on ventricular long-axis function in healthy subjects. Cardiovasc Ultrasound. 2008;6(9):1-10. doi:10.1186/1476-7120-69.

22. Cappelletti S, Daria P, Sani G, Aromatario M. Caffeine: Cognitive and physical performance enhancer or psychoactive drug? Curr Neuropharmacol. 2015;13(1):71-88.

23. Li F, Hullar MA, Beresford SA, Lampe JW. Variation of glucoraphanin metabolism in vivo and ex vivo by human gut bacteria. $\mathrm{Br}$ J Nutr. 2011;106(3):408-416. doi:10.1017/S0007114511000274.Variation.

24. Schilling K, Gao Y, Stepniewska I, Choe AS, Landman BA, Anderson AW. Reproducibility and variation of diffusion measures in the squirrel monkey brain, in vivo and ex vivo. Magn Reson Imaging. 2017;35(2017):29-38. doi:10.1016/j.mri.2016.08.015.

25. Meulman TJ, Bakker J, Bos EJ Van Den. Case report: Ischemic cardiomyopathy and cerebral infarction in a young patient associated with khat chewing. Case Rep Radiol. 2015;2015:1-4. doi:10.1155/2015/893176.

26. Ridder S De, Eerens F, Hofstra L. Khat rings twice: Khat-induced thrombosis in two vascular territories. Netherlands Hear J. 2007;15(7):269-270. 
27. Wabe NT. Chemistry, pharmacology, and toxicology of khat (Catha Edulis Forsk ): A review. Addict Heal. 2011;3(3-4):137-149.

28. Vijayapandi P, Annabathina V, B S, et al. In vitro anticholinergic and antihistaminic activities of Acorus calamus linn leaves extracts. Afriican J Tradit Complement Altern Med. 2013;10(1):95-101.

29. Franconi F, Brunelleschi S, Steardo L, Cuomo V. Gender differences in drug responses. Pharmacol Res. 2007;55:81-95. doi:10.1016/j.phrs.2006.11.001.

30. Denayer T, Stöhrn T, Van Roy M. Animal models in translational medicine: Validation and prediction. New Horizons Transl Med. 2014;2(1):5-11. doi:10.1016/j.nhtm.2014.08.001.

31. Faber J, Fonseca LM. How sample size influences research outcomes. Dental Press J Orthod. 2014;19(4):27-29. doi:10.1590/2176-9451.19.4.027-029.ebo.

32. Tesfaye F, Byass P, Wall S, Berhane Y, Bonita R. Association of smoking and khat (Catha edulis Forsk) use with high blood pressure among adults in Addis Ababa, Ethiopia, 2006. Prev Chronic Dis. 2008;5(3):A89-A95.

33. Birhane BW, Birhane MW. The effect of Khat ( Catha edulis ) chewing on blood pressure among male adult Chewers, Bahir Dar, North West Ethiopia. Sci J Public Heal. 2014;2(5):461-468.

doi:10.11648/j.sjph.20140205.23.

34. Seifu W, Hussein M, Ibrahim M, Sigale A. Behavioral risk factors of hypertension among pastoral and agro pastoral adult communities, Eastern Ethiopia, Somali Regional State, 2016. J Trop Dis. 2017;5(1):1-6. 891X.1000234.

35. Benetos A, Zureik M, Morcet J, et al. A decrease in diastolic blood pressure combined with an increase in systolic blood pressure is associated with a higher cardiovascular mortality in men. J Am Coll Cardiol. 2000;35(3):673-680. doi:10.1016/S0735-1097(99)00586-0.

36. Al-Motarreb AL, Broadley KJ. Coronary and aortic vasoconstriction by cathinone, the active constituent of khat. Auton Autacoid Pharmacol. 2003;23(5-6):319-326. doi:10.1111/j.1474-8673.2004.00303.x.

37. Baker KE, Herbert AA, Broadley KJ.
Vasoconstriction of porcine left anterior descending coronary artery by ecstasy and cathinone is not an indirect sympathomimetic effect. Vascul Pharmacol. 2007;47(1):10-17. doi:10.1016/j.vph.2007.03.001.

38. Laswar AKN, Darwish $\mathrm{H}$. Prevalence of cigarette smoking and khat chewing among Aden University Medical Students and their relationship to blood pressure and body mass index. Saudi J Kidney Dis Transplant. 2009;20(5):862-866.

39. Tirapelli CR, Bonaventura D, Tirapelli LF, De Oliveira AM. Mechanisms underlying the vascular actions of endothelin 1, angiotensin II and bradykinin in the rat carotid. Pharmacology. 2009;84(2):111 126. doi:10.1159/000231974.

40. Nakajima M, Hoffman R, Absi M. Poor working memory and reduced blood pressure levels in concurrent users of khat and Tobacco. Nicotine Tob Res. 2014;16(3):279-287.

doi:10.1093/ntr/ntt139.

41. Cheng WC, Shu WY, Li CY, et al. Intra- and inter-individual variance of gene expression in clinical studies. PLoS One. 2012;7(6):1-8.

doi:10.1371/journal.pone.0038650.

42. Peper A. Aspects of the relationship between drug dose and drug effect. DoseResponse. $2009 ; 7(2): 172-192$. doi:10.2203/dose-response.08-019.Peper.

43. Wong DR, Willett WC, Rimm EB. Smoking, hypertension, alcohol consumption, and risk of abdominal aortic aneurysm in men. Am J Epidemiol. 2007;165(7):838-845. doi:10.1093/aje/kwk063.

44. Mortand JR, Kruse HR. Timing of blood pressure measurement related to caffeine consumption. Ann Pharmacother. 2007;42(1):105-110.

45. Sharma $\mathrm{P}$, Murthy $\mathrm{P}$, Bharath MMS. Chemistry, metabolism, and toxicology of cannabis: Clinical implications. Iran J Psychiatry. 2012;7(4):149-156.

46. Liberati A, Altman DG, Tetzlaff J, et al. The PRISMA statement for reporting systematic reviews and meta-analyses of studies that evaluate health care interventions: explanation and elaboration. $J$ Clin Epidemiol. 2009;62(10):1-34. doi:10.1016/j.jclinepi.2009.06.006. 


\section{APPENDIX}

Table 1: A summary of the khat influences on the cardiovascular system based on human studies/reports $(n=10)$.

\begin{tabular}{|c|c|c|c|c|c|c|}
\hline \multicolumn{7}{|c|}{ Human Studies / Reports } \\
\hline \multirow[b]{2}{*}{$\begin{array}{l}\text { Author(s), } \\
\text { year }\end{array}$} & \multirow[b]{2}{*}{$\begin{array}{c}\text { Gender/sample size (n), study design, dose } \\
\text { (Study duration) }\end{array}$} & \multicolumn{5}{|c|}{ Khat effects on the cardiovascular system (CVS) } \\
\hline & & $\begin{array}{l}\text { Heart rate } \\
\text { (beats } \\
\text { /min) }\end{array}$ & \multicolumn{2}{|c|}{$\begin{array}{l}\text { Blood pressure } \\
(\mathrm{mmHg})\end{array}$} & $\begin{array}{l}\text { Other CVS } \\
\text { effects }\end{array}$ & Study strengths and weaknesses \\
\hline $\begin{array}{l}\text { Brenneisen } \\
\text { et al. } \\
1990 \text { a, b }\end{array}$ & $\begin{array}{l}M(\mathrm{n}=6), \text { placebo-controlled balanced } \\
\text { experimental study, } 0.5 \mathrm{mg} / \mathrm{kg} \text { cathinone } \\
\text { oral capsule or placebo (8-hours study). }\end{array}$ & $\uparrow(S)$ & $\uparrow(S)$ & $\uparrow(S)$ & - & $\begin{array}{l}\text { In vivo study that showed khat effects } \\
\text { on CVS but subjects grouping was } \\
\text { unclear, } n \text { was small and study } \\
\text { duration was short. }\end{array}$ \\
\hline $\begin{array}{l}\text { Widleret } \\
\text { al. } \\
\text { 1994a, b }\end{array}$ & $\begin{array}{l}M(\mathrm{n}=6) \text {, double-blinded placebo-controlled } \\
\text { balanced study, khat leaves extracts } \\
\text { containing } 0.8 \mathrm{mg} / \mathrm{kg} \text { cathinone or placebo } \\
\text { (10-hours study). }\end{array}$ & $\uparrow(\mathrm{NS})$ & $(\mathrm{S})$ & $\uparrow(S)$ & - & $\begin{array}{l}\text { In vivo double-blinded study that } \\
\text { showed khat effects on CVS but } n \text { was } \\
\text { small and study duration was short. }\end{array}$ \\
\hline $\begin{array}{l}\text { Hassan et } \\
\text { al. } \\
2005 \text { a, b }\end{array}$ & $\begin{array}{l}\text { M ( } \mathrm{n}=63) \text {, double-blinded } 3 \text { arm cross-over } \\
\text { placebo controlled study, khat dose } \\
\text { standardised but dosage was unclear + } \\
\text { either placebo or } 50 \mathrm{mg} \text { atenolol or } 25 \mathrm{mg} \\
\text { indoramin (4-months study). }\end{array}$ & $(S)$ & $\uparrow(S)$ & $\uparrow(S)$ & - & $\begin{array}{l}\text { In vivo double-blinded study that } \\
\text { showed khat effects on CVS mediated } \\
\text { via } B \text {-adrenoceptor. But, } n \text { was small, } \\
\text { study duration was short, khat dose } \\
\text { used was unclear. }\end{array}$ \\
\hline $\begin{array}{l}\text { Laswar and } \\
\text { Darwish } \\
\text { 2009b }\end{array}$ & $\begin{array}{l}M \text { and } F(n=100) \text {, cross-sectional study, } 54 \% \\
\text { chewers vs } 46 \% \text { non-chewers, study done in } \\
\text { year } 2004 .\end{array}$ & - & $\mathrm{F}$ (NS) & $F(N S)$ & - & $\begin{array}{l}\text { Small } n \text {, did not exclude smokers and } \\
\text { other HPT risk factors but } \\
\text { demonstrated association between } \\
\text { increased study tension (seniority of } \\
\text { medical students) and khat usage. }\end{array}$ \\
\hline $\begin{array}{l}\text { Getahunet } \\
\text { al. } \\
2010 \text { a, b }\end{array}$ & $\begin{array}{l}M \text { and } F(n=667) \text {, cross-sectional study, } \\
50.3 \% \text { chewers vs } 49.7 \% \text { non-chewers } \\
\text { (Study duration not specified). }\end{array}$ & (S) & $\uparrow(N S)$ & $\uparrow(S)$ & - & $\begin{array}{l}\text { Moderate } n \text { size, use of consistent } \\
\text { data collection methods but } \\
\text { significant higher smokers among } \\
\text { chewers than non-chewers affected } \\
\text { study reliability. }\end{array}$ \\
\hline
\end{tabular}




\begin{tabular}{|c|c|c|c|c|c|c|}
\hline $\begin{array}{l}\text { Birhane } \\
\text { and } \\
\text { Birhane } \\
2014^{b}\end{array}$ & $\begin{array}{l}\text { M ( } n=422) \text {, cross-sectional study, all chewers } \\
\text { (9-month study). }\end{array}$ & - & (S) & $(S)$ & - & $\begin{array}{l}\text { Intra-population study with moderate } \\
\mathrm{n} \text { size, included smokers, alcoholics, } \\
\text { did not justify how khat affects BP. }\end{array}$ \\
\hline $\begin{array}{l}\text { Nakajima } \\
\text { et al. } \\
2014^{\mathrm{b}}\end{array}$ & $\begin{array}{l}M \text { and } F(n=74) \text {, cross-sectional, } 49 \text { khat } \\
\text { chewers vs } 25 \text { non-chewers } \\
\text { (1-day study). }\end{array}$ & - & (S) & (S) & - & $\begin{array}{l}\text { Correlated khat usage and reduced BP } \\
\text { and cognition but failed to explain the } \\
\text { mechanism and small } n \text {. }\end{array}$ \\
\hline $\begin{array}{l}\text { Sallamet } \\
\text { al. } 2016^{\text {a }}\end{array}$ & $\begin{array}{l}\text { Gender unspecified }(\mathrm{n}=21) \text {, experimental } \\
\text { crossover study, } 33 \mathrm{ml} \text { placebo juices or } \\
33 \mathrm{ml} \text { juices }+45 \mathrm{~g} \text { ground khat leaves ( } 3- \\
\text { months study). }\end{array}$ & (S) & - & - & - & $\begin{array}{l}\text { In vivo human study, subjects } \\
\text { grouping unclear, small } n \text {. Unreliable } \\
\text { findings as it studied khat effects on } \\
\text { HR post-exercise. }\end{array}$ \\
\hline $\begin{array}{l}\text { Seifu et al. } \\
2017^{b}\end{array}$ & $\begin{array}{l}M \text { and } F(n=330), \text { cross-sectional study, } \\
91.81 \% \text { khat chewers vs } 8.19 \% \text { non-chewers } \\
(1-\text {-month study). }\end{array}$ & - & \multicolumn{2}{|c|}{$\begin{array}{l}\text { Khatrasied BP but } \\
\text { it was unclear } \\
\text { whether it raised } \\
\text { SBP, DBP or both. }\end{array}$} & - & $\begin{array}{l}\text { Moderate } n \text { size, almost all subjects } \\
\text { are khat chewers, but did not exclude } \\
\text { other HPT risk factors like smoking. }\end{array}$ \\
\hline
\end{tabular}

All the human studies/reports were arranged according to chronological order.

$\uparrow$ means increase; $\downarrow$ means decrease.

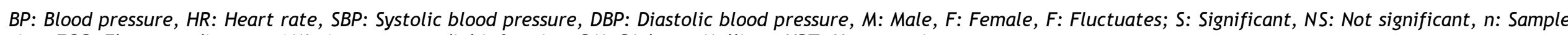
size, ECG: Electrocardiogram, AMI: Acute myocardial infarction, DM: Diabetes Mellitus, HPT: Hypertension

${ }^{a}$-Khat and heart rate theme; ${ }^{b}$-Khat and blood pressure theme 
Table 2: A summary of the khat impacts on the cardiovascular system based on animal studies/reports $(\mathrm{n}=4)$.

\begin{tabular}{|c|c|c|c|c|c|c|}
\hline \multicolumn{7}{|c|}{ Animal studies / Reports } \\
\hline \multirow{3}{*}{$\begin{array}{l}\text { Author(s), } \\
\text { year }\end{array}$} & \multirow{3}{*}{$\begin{array}{c}\text { Study model/gender, study design } \\
\text { (sample size, n), dose (study duration) }\end{array}$} & \multicolumn{5}{|c|}{ Khat effects on the cardiovascular system (CVS) } \\
\hline & & \multirow{2}{*}{$\begin{array}{l}\text { Heart rate } \\
\text { (beats } \\
\text { /min) }\end{array}$} & \multicolumn{2}{|c|}{$\begin{array}{c}\text { Blood pressure } \\
(\mathrm{mmHg})\end{array}$} & \multirow[t]{2}{*}{$\begin{array}{l}\text { Other CVS } \\
\text { effects }\end{array}$} & \multirow[t]{2}{*}{ Study strengths and weaknesses } \\
\hline & & & SBP & DBP & & \\
\hline $\begin{array}{l}\text { Al-Motarreb } \\
\text { and Broadly } \\
2003^{b}\end{array}$ & $\begin{array}{l}\text { Dunkin-Hartley guinea-pigs/M, } \\
\text { experimental organ baths (no. of baths } \\
\text { used not clearly stated), cathinone } 0.01 \text { - } \\
1000 \mu \text { + use of other sympathomimetic } \\
\text { and its blockers ( } 1 \text {-day study). }\end{array}$ & - & - & - & $\begin{array}{l}\text { Cathinone } \\
\text { significantly } \\
\text { increased } \\
\text { coronary } \\
\text { vasoconstriction } \\
\text { in a dose- } \\
\text { dependent } \\
\text { manner. }\end{array}$ & $\begin{array}{l}\text { Ex vivo study, direct assessed khat } \\
\text { effects on tissue and proposed } \\
\text { possible mechanism but } n \text { unclear, } \\
\text { effects on human might differ. }\end{array}$ \\
\hline $\begin{array}{l}\text { Baker et al. } \\
2007 \text { b }\end{array}$ & $\begin{array}{l}\text { Guinea pig/M, experimental organ baths } \\
\text { (no. of baths used not clearly stated), } \\
\text { cathinone } 3-300 \mu M+\text { use of other } \\
\text { sympathomimetic and its blockers (1-day } \\
\text { study). }\end{array}$ & - & - & - & $\begin{array}{l}\text { Cathinone } \\
\text { significantly } \\
\text { induced } \\
\text { coronary } \\
\text { vasoconstriction } \\
\text { in a dose- } \\
\text { dependent } \\
\text { manner. } \\
\end{array}$ & $\begin{array}{l}\text { Ex vivo study, direct assessed khat } \\
\text { effects on tissue and proposed } \\
\text { possible mechanism but n unclear, } \\
\text { effects on human might differ. }\end{array}$ \\
\hline $\begin{array}{l}\text { Al-Hashem } \\
\text { et al. } 2012 \text { a }\end{array}$ & $\begin{array}{l}\text { White albino rabbit/M, experimental organ } \\
\text { baths }(n=6), 50,100 \text { and } 250 \mathrm{mg} / \mathrm{ml} \text { khat } \\
\text { leaves extracts ( } 90 \text { minutes). }\end{array}$ & $(\mathrm{S})$ & - & - & $\begin{array}{l}\text { Decreased } \\
\text { myocardial } \\
\text { contractility. }\end{array}$ & $\begin{array}{l}\text { Ex vivo study, justified results well } \\
\text { but } n \text { was small, short study duration. }\end{array}$ \\
\hline $\begin{array}{l}\text { Al-Hashem } \\
\text { and Shatoor } \\
2012 \text { a, b }\end{array}$ & $\begin{array}{l}\text { Wistar rat } / M \text {, experimental }(n=10 \text { for } \\
\text { control and } n=10 \text { for khat leaves extracts } \\
\text { treated group), oral dose of } 3 \mathrm{mg} / \mathrm{kg}(60 \\
\text { minutes). }\end{array}$ & $(\mathrm{S})$ & $\uparrow(S)$ & $\uparrow(S)$ & $\begin{array}{l}\text { Decreased PR } \\
\text { interval and } \\
\text { prolonged QT on } \\
\text { ECG. }\end{array}$ & $\begin{array}{l}\text { In vivo study, rats grouping unclear, } \\
\text { small } n \text {, short study duration and did } \\
\text { not clearly justify how khat affects BP } \\
\text { and HR. }\end{array}$ \\
\hline
\end{tabular}

All the animals studies/reports were arranged according to the chronological order.

$\uparrow$ means increase; $\downarrow$ means decrease.

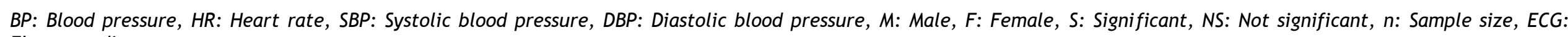
Electrocardiogram

${ }^{a}{ }_{-K h a t}$ and heart rate theme; ${ }^{{ }}$-Khat and blood pressure theme 